\title{
Evaluation of Surface Sediment Quality in Rivers with Fish Farming Potential (Peru) Using Indicators of Contamination, Accumulation and Ecological Risk of Heavy Metals and Arsenic
}

\author{
María Custodio ${ }^{*}$, Anthony Fow² ${ }^{2}$ Richard Peñaloza' ${ }^{1}$ Fernán Chanamé1, Deyvis Cano \\ 1 Universidad Nacional del Centro del Perú, Av. Mariscal Castilla №3909-4089, Huancayo, Perú \\ 2 Universidad Nacional del Callao, Facultad de Ingeniería Ambiental y de Recursos Naturales, \\ Av. Juan Pablo II 306, Bellavista-Callao, Perú \\ *Corresponding author's e-mail: mcustodio@uncp.edu.pe
}

\begin{abstract}
Surface sediment quality of potential rivers in Peru was evaluated using indicators of contamination, accumulation and ecological risk of heavy metals and As. Surface sediment samples were collected at 54 sampling sites in the Tishgo and Chia rivers during 2018. The determination of $\mathrm{Cu}, \mathrm{Pb}, \mathrm{Zn}$ and As was performed by flame atomic absorption spectrophotometry. The results revealed the decreasing order of the mean concentrations of heavy metals and $\mathrm{As}$ in the Chia River of $\mathrm{Zn}>\mathrm{Cu}>\mathrm{As}>\mathrm{Pb}$ and Tishgo of $\mathrm{Zn}>\mathrm{Pb}>\mathrm{As}>\mathrm{Cu}$. The PLI for the Tishgo River were greater than one (PLI $>1$ ) denoting the deterioration it has been experiencing. In the Chia River, $60 \%$ of the sampling sites indicated no appreciable contamination by these elements $(\mathrm{PLI}<1)$. The $\mathrm{I}_{\mathrm{geo}}$ values of As in both rivers showed a state of contamination, from moderately to severely contaminated. In the Tishgo River the potential ecological risk varied from low to moderate and in the Chia River from low to considerable. Finally, this study reveals the applicability of the evaluation indexes of contamination, accumulation and potential ecological risk of toxic metals so that special control measures can be adopted.
\end{abstract}

Keywords: sediment quality, rivers, fish potential, pollution, accumulation, ecological risk.

\section{INTRODUCTION}

The aquatic ecosystems support a wide range of organisms, including microorganisms, invertebrates, insects, plants, and fish (Marshall, 2013). In addition, these ecosystems provide goods and services that are exploited by humans (Meyer, 2010). Although relevant to the environment, aquatic ecosystems are sinks for various pollutants, such as heavy metals, pesticides, and other synthetic or natural pollutants. The slightest effects reveal changes in growth, reproduction, behavior and survival of aquatic species. Fish can act as indicators of possible larger-scale pollution problems. However, the impacts of these pollutants on aquatic environments are usually visualized when the consequences have reached critical points, such as fish kills or algal blooms (Davies \& Govedich, 2001).
The contamination by metals in aquatic ecosystems has been of great concern due to their toxicity, persistence and accumulation in these habitats (Varol, 2011). Metals have less mobility in water columns and their continuous accumulation in natural aquatic systems promotes their precipitation to sediments. Which constitute potential sources of heavy metals to the water column and accumulate in aquatic flora and fauna (Raza et al., 2016); (Dash, Borah, \& Kalamdhad, 2021). The transfer of metals from sediments to water columns and their subsequent bioaccumulation in the food chain are detrimental to both the aquatic ecosystem and human health (Williams \& Antoine, 2020). At the aquatic ecosystem level it can affect through the accumulation of metals in the body of fish (Chanamé et al., 2014), decreasing species diversity and even causing their complete disappearance (Haris et al., 2017; Williams 
\& Antoine, 2020). In this sense, metals also affect public health due to the fact that people make use of the water and consume fish caught from contaminated rivers, facing serious consequences that pose a risk to their integrity, as some of the metals are considered carcinogenic (Arisekar et al., 2020; Li et al., 2017).

The central and southern regions of Peru are the main production areas for rainbow trout (Oncorhynchus mykiss), due to their environmental characteristics and conditions for the development of a good culture (Ramírez et al., 2018). In the period from 2006 to 2017, trout production in Peru had an increase of 3457.37 metric tons, and of this increase, the productions of Junín and Puno accounted for $85 \%$ of national production. The growing demand for the consumption of this fish has motivated the increase of fish farms dedicated to this crop to satisfy the emerging market (Cacchi, 2019). In this sense, it is important to know the quality of the aquatic ecosystem where these fish production practices are developed in Peru. Therefore, tools are needed to comprehensively assess the state of this ecosystem. The objective of this study was to evaluate the quality of surface sediment in rivers with fish farming potential (Peru) using indicators of contamination, accumulation and ecological risk of heavy metals and arsenic.

\section{MATERIALS AND METHODS}

\section{Study area}

The Tishgo and Chia rivers are located in the Mantaro river basin, central Peru, between latitudes $10^{\circ} 34^{\prime \prime} \mathrm{S}-13^{\circ} 35^{\prime \prime} \mathrm{S}$ and longitudes $73^{\circ} 55^{\prime \prime} \mathrm{W}-76^{\circ} 40^{\prime \prime} \mathrm{W}$, at an altitude of 3460 and 4100 m.a.s.l., respectively. One of the main uses of the waters of the Tishgo and Chía rivers is for fish production in the Yauli and Huancayo provinces, respectively. The characteristics of these rivers, like most of those belonging to the Mantaro basin, include mountainous areas, steep drops where agriculture and fish farming are also carried out (Figure 1).

\section{Surface sediment collection}

Surface sediment (top $10 \mathrm{~cm}$ ) was collected at 54 sampling sites on the Tishgo and Chia rivers during 2018 using a modified Ekman dredge. Three sediment samples were collected at each sampling site. Sediment samples were digested according to USEPA method 3051A with some modifications. In brief, 1.00 gram of dry sample was transferred to a $150 \mathrm{ml}$ beaker, $2.5 \mathrm{ml}$ of nitric acid and $10 \mathrm{ml}$ of hydrochloric acid were added. The beaker was covered with a watch glass

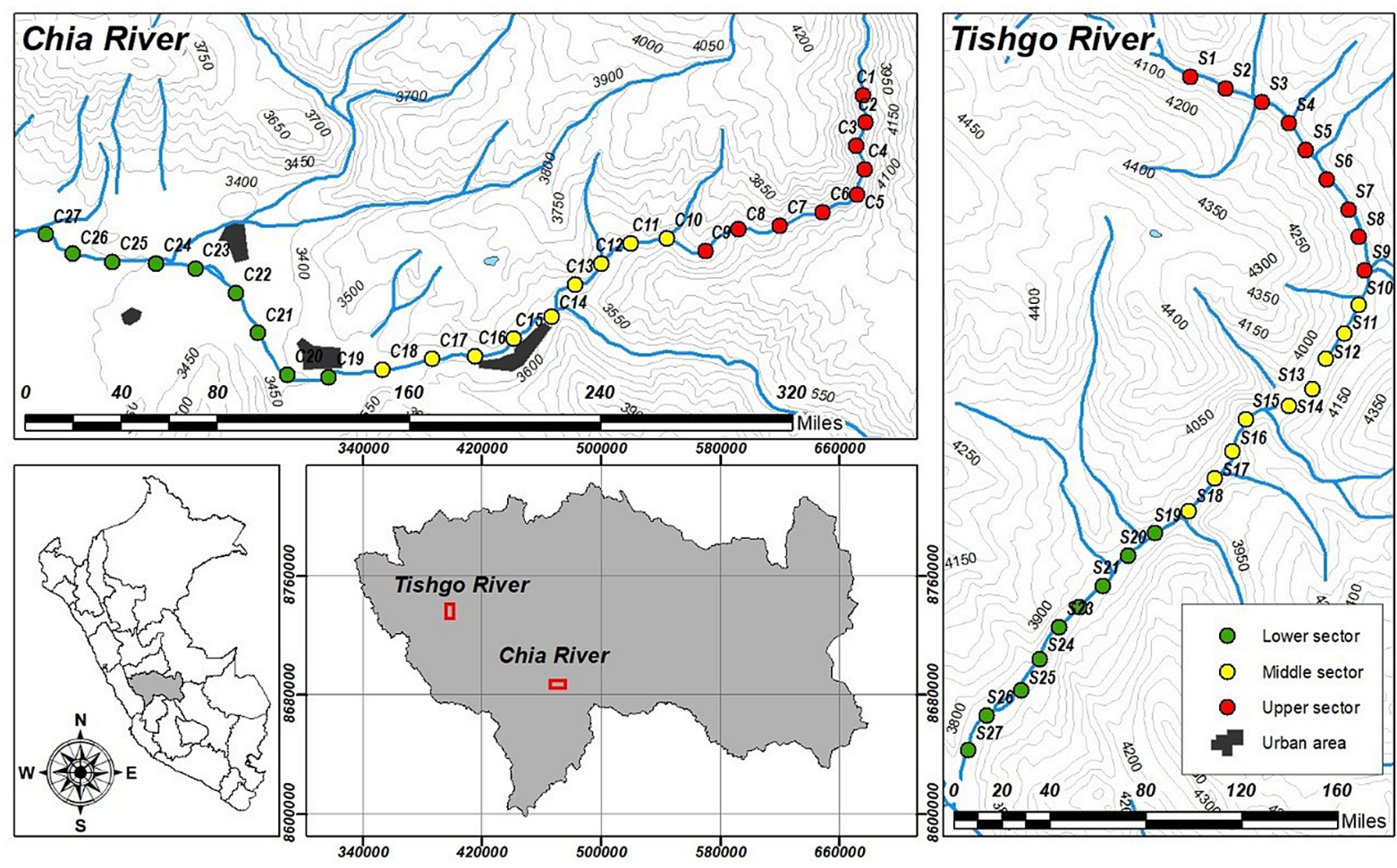

Figure 1. Location map of the study area in the Tishgo and Chia rivers in central Peru. 
and taken to digestion by the microwave-assisted method. The established digestion program was: 17 minutes at $120^{\circ} \mathrm{C}, 15$ minutes at $210^{\circ} \mathrm{C}$ and 30 minutes at $210^{\circ} \mathrm{C}$. After cooling, the digestion product was transferred to a $100 \mathrm{ml}$ flask and the volume was filled with ultrapure water. The sample was stored at $4{ }^{\circ} \mathrm{C}$ and filtered before analysis. The determination of heavy metals and arsenic was carried out by flame atomic absorption spectrophotometry (air-acetylene) using a VARIAN AA 240 atomic absorption spectrometer. The standards were then read at different wavelengths for each element.

\section{Sediment quality indexes}

\section{Contamination factor}

The contamination factor (CF), expressed as the ratio between the concentration of each metal in the sediment and the background value, was applied to quantify the metal contamination status of the sediment as a function of its concentrations in the sample and its background concentration.

The CF values were calculated with equation (1).

$$
\mathrm{CF}=\frac{\mathrm{C}_{m} \text { sample }}{\mathrm{C}_{m} \text { background }}
$$

Where, ' $\mathrm{Cm}$ sample' is the concentration of heavy metals in the sediment sample and ' $\mathrm{Cm}$ background' is the average concentration of heavy metal present in the upper continental plate raised by Taylor \& McLennan (1995). The categories of $\mathrm{CF}<1$, is described as low contamination factor; $1<\mathrm{CF}<3$, as moderate contamination factor; $3<$ $\mathrm{CF}<6$, as considerable contamination factor; and $\mathrm{CF} \geq 6$, as very high contamination factor (ElAmier, Elnaggar, \& El-Alfy, 2016).

\section{Pollution load index}

The pollution load index (PLI) was applied to determine the metal contamination in surface sediments using the procedure of Tomlinson et al., 1980, equation (2).

$$
\mathrm{PLI}=\left(\mathrm{CF}_{1} \times \mathrm{CF}_{2} \times \mathrm{CF}_{3} \times \ldots \mathrm{CF}_{n}\right)^{1 / n}
$$

Where, $n$ is the number of metals and CF is the contamination factor. The PLI is a powerful tool for assessing heavy metal contamination. A PLI value of zero indicates perfection, a value of one indicates the presence of only basic levels of contaminants and values above one would indicate progressive deterioration of the site and estuarine quality.

\section{Geo-accumulation index}

The geo-accumulation index $\left(\mathrm{I}_{\text {geo }}\right)$ was determined to find the metallic contamination of sediment samples. This index was presented by Müller (1979) to determine the difference in concentrations between the samples and the average values that exist naturally in the continental plate. The calculation of this parameter was carried out by means of the equation (3).

$$
\mathrm{I}_{\text {geo }}=\log _{2} \frac{\mathrm{C}_{\mathrm{n}}}{1.5 \times \mathrm{B}_{\mathrm{n}}}
$$

Where $C_{n}$ represents the concentration of the metal determined in the sediment, Bn represents the average value of these metals in the upper continental plate as proposed by Taylor \& McLennan (1995). The $\mathrm{I}_{\text {geo }}$ according to Müller (1979) is classified into $7^{\text {geo }}$ levels: $I_{\text {geo }} \leq 0$, level 0 (practically uncontaminated); $0<\mathrm{I}_{\text {geo }}<1$, level 1 (uncontaminated to moderately contaminated); 1 $<\mathrm{I}_{\text {geo }}<2$, level 2 (moderately contaminated); $2<$ $\mathrm{I}_{\text {geo }}<3$, level 3 (moderately to heavily polluted); $3<\mathrm{I}_{\text {geo }}<4$, level 4 (heavily polluted); $4<\mathrm{I}_{\text {geo }}<$ 5 level 5 (heavily to extremely polluted); $\mathrm{I}_{\text {geo }}>5$, level 6 (extremely polluted).

\section{Ecological risk assessment and potential ecological risk index}

The ecological risk assessment was carried out by calculating the ecological risk factor (Er), using the method developed by Hakanson (1980) to evaluate the potential effect of heavy metals in sediments on the organisms of the aquatic ecosystem. This effect is evaluated for each metal individually. The calculation of this factor was evaluated by means of the equation (4).

$$
\mathrm{Er}=\operatorname{Tr} \times \mathrm{CF}
$$

The contamination factor $\mathrm{CF}$ and a coefficient called " $T r$ ", which refers to a specific toxicity index for each metal, were used; these indexes were established by Hakanson (1980). On the other 
hand, the potential ecological risk index (Ri) calculated using equation (5) was determined by the sum of the "Er" evaluated at each site.

$$
\operatorname{Ri}=\sum \operatorname{Er}
$$

The ecological risk factor $(\mathrm{Er})$ is classified as follows: $\mathrm{Er}<40$, represents low ecological risk potential; $40<\mathrm{Er}<80$, represents moderate ecological risk; $80<\mathrm{Er}<160$, represents considerable ecological risk; between $160<\mathrm{Er}<320$, represents high ecological risk potential and factors greater than 320 represent very high ecological risk potential. In the case of the potential ecological risk index (Ri), it is classified under the following ranges: $\mathrm{Ri}<150$ is classified as low ecological risk; $150 \leq \mathrm{Ri}<300$ is classified as moderate ecological risk; $300 \leq \mathrm{Ri}<600$ is classified as considerable ecological risk and $\mathrm{Ri} \geq 600$ is classified as very high ecological risk.

\section{RESULTS AND DISCUSSION}

\section{Distribution of heavy metals and arsenic in sediment of rivers with fish farming potential}

Descriptive statistics of heavy metal and arsenic concentrations in surface sediment of the Chia and Tishgo rivers are presented in Table 1 along with threshold values of probable effect concentration (PEC) (MacDonald, Ingersoll, \& Berger, 2000), upper continental crust (UCC) reference values (Taylor \& McLennan, 1995) and interim sediment quality guidelines (ISQG) values (Canadian Council of Ministers of the Environment, 2004). The decreasing order of mean heavy metal and metalloid concentrations in the Tishgo River was $\mathrm{Zn}>\mathrm{Pb}>\mathrm{As}>\mathrm{Cu}$ and in the Chia River it was $\mathrm{Zn}>\mathrm{Cu}>\mathrm{As}>\mathrm{Pb}$. In the Tishgo River, the highest mean concentrations of $\mathrm{Zn}, \mathrm{Cu}$, As and $\mathrm{Pb}$ were recorded in the lower course of the river. Meanwhile, in the Chia River, the highest mean concentrations were recorded in the upper course of the river. The mean concentrations of heavy metals and metalloids recorded in the rivers studied were lower than the threshold values of the PEC. In the Chía River, the mean concentrations of $50 \%$ of the elements studied $(\mathrm{Cu}, 19.26 \mathrm{mg}$ $\mathrm{kg}^{-1}$; As, $11.32 \mathrm{mg} \mathrm{kg}^{-1}$ ) exceeded the ISQG values $\left(18.70 \mathrm{mg} \mathrm{kg}^{-1} ; 124 \mathrm{mg} \mathrm{kg}^{-1} ; 7.24 \mathrm{mg} \mathrm{kg}{ }^{-1}\right.$, respectively). While, in the Tishgo River, the mean concentrations of $75 \%$ of the elements evaluated $\left(\mathrm{Cu}, 21.17 \mathrm{mg} \mathrm{kg}^{-1} ; \mathrm{Z}, 125.08 \mathrm{mg} \mathrm{kg}^{-1}\right.$; As, $19.34 \mathrm{mg} \mathrm{kg}^{-1}$ ) exceeded the ISQG values. All chemical elements evaluated in the Tishgo River exceeded the UCC reference values.

The maximum $\mathrm{Cu}$ concentration $(20.87 \mathrm{mg}$ $\mathrm{kg}^{-1}$ ) was recorded in the upper course of the Chía River and the lowest concentration (17.25 mg $\mathrm{kg}^{-1}$ ) in the lower course. While the distribution of this metal in the Tishgo river presented a different pattern from that of the Chia River, with the maximum $\mathrm{Cu}$ concentration being recorded in the lower course of the river $(23.41 \mathrm{mg} / \mathrm{kg})$. However, the maximum $\mathrm{Cu}$ concentrations in both rivers were lower than the UCC reference values $\left(25 \mathrm{mg} \mathrm{kg}^{-1}\right)$. The maximum $\mathrm{Pb}$ concentrations at the sampling sites in each sector in both rivers showed irregular distribution patterns ranging from 7.85 to $11.05 \mathrm{mg} \mathrm{kg}^{-1}$ and from 24.08 to $29.31 \mathrm{mg} \mathrm{kg}^{-1}$ in the Chia and Tishgo rivers, respectively. In the Tishgo River, the maximum concentrations of $\mathrm{Pb}$ and $\mathrm{Zn}$ in the different sectors exceeded the UCC reference value $(25 \mathrm{mg}$ $\mathrm{kg}^{-1}, 71 \mathrm{mg} \mathrm{kg}^{-1}$, respectively). In the Chía River, the maximum $\mathrm{Zn}$ concentration recorded in the upper river $(77.99 \mathrm{mg} / \mathrm{kg})$ was higher than the UCC reference value $\left(71 \mathrm{mg} \mathrm{kg}^{-1}\right)$. In both rivers, all maximum As concentrations were higher than the UCC reference value $\left(1.5 \mathrm{mg} \mathrm{kg}^{-1}\right)$ (Figure 2). These results could be related to domestic wastewater discharges, metallic input from tributary rivers coming from areas with operational mining units, runoff from agricultural areas in the study area. The use of fertilizers and pesticides could be responsible for the release of $\mathrm{Cu}, \mathrm{Cd}, \mathrm{Pb}$ and Zn (Barra-Rocha, Fernandes-Costa, \& PimentaAzevedo, 2019) and significant contribution in the sediments collected in the studied rivers.

The spatial distribution of heavy metals and arsenic in water bodies depends on natural and anthropogenic sources. Trace metal contents from natural sources derive mainly from soils and mineral weathering (Custodio et al., 2018). $\mathrm{Cu}$ is one of the essential nutrients required by biological systems for the activation of some enzymes. However, in aquatic environments $\mathrm{Cu}$ is toxic to a variety of organisms, even at very low concentrations. Likewise, the high concentrations of $\mathrm{Cu}$ in the upper course of the Chia River and lower course of the Tishgo River would be due to anthropogenic contributions. $\mathrm{Pb}$ is a heavy metal found in nature in the tetravalent $\left(\mathrm{Pb}^{+4}\right)$ and divalent $\left(\mathrm{Pb}^{+2}\right)$ forms. The divalent form is predominantly and slightly soluble in water (Deng et al., 2008). 
Table 1. Descriptive statistics (SD) of heavy metals and arsenic in sediment of the Tishgo and Chia rivers, threshold values of probable effects, reference material and sediment quality guidelines $\left(\mathrm{mg} \mathrm{kg}^{-1}\right)$.

\begin{tabular}{|c|c|c|c|c|c|c|c|c|c|c|}
\hline \multirow[b]{2}{*}{ Element } & \multirow[b]{2}{*}{ DS } & \multicolumn{3}{|c|}{ Tishgo } & \multicolumn{3}{|c|}{ Chía } & \multirow[b]{2}{*}{ PEC } & \multirow[b]{2}{*}{ UCC } & \multirow[b]{2}{*}{ ISQG } \\
\hline & & $\begin{array}{l}\text { Upper } \\
\text { course }\end{array}$ & $\begin{array}{l}\text { Middle } \\
\text { course }\end{array}$ & $\begin{array}{l}\text { Lower } \\
\text { course }\end{array}$ & $\begin{array}{l}\text { Upper } \\
\text { course }\end{array}$ & $\begin{array}{l}\text { Middle } \\
\text { course }\end{array}$ & $\begin{array}{l}\text { Lower } \\
\text { course }\end{array}$ & & & \\
\hline \multirow[t]{4}{*}{$\mathrm{Cu}$} & Mean & 17.98 & 15.58 & 21.17 & 19.26 & 16.30 & 15.48 & 149 & 25 & 18.70 \\
\hline & SD & 3.01 & 1.20 & 1.92 & 1.29 & 0.91 & 1.26 & & & \\
\hline & Max & 22.08 & 16.93 & 23.41 & 20.87 & 18.46 & 17.25 & & & \\
\hline & Min & 12.76 & 13.21 & 18.17 & 16.64 & 15.60 & 14.00 & & & \\
\hline \multirow[t]{4}{*}{$\mathrm{Pb}$} & Mean & 21.27 & 19.93 & 25.76 & 8.03 & 7.27 & 5.02 & 128 & 20 & 30.20 \\
\hline & SD & 4.81 & 3.84 & 3.40 & 1.50 & 1.54 & 1.37 & & & \\
\hline & Max & 27.61 & 24.08 & 29.31 & 11.05 & 10.70 & 7.85 & & & \\
\hline & Min & 14.15 & 15.42 & 20.12 & 5.24 & 5.53 & 3.56 & & & \\
\hline \multirow[t]{4}{*}{$\mathrm{Zn}$} & Mean & 101.76 & 98.81 & 125.08 & 66.81 & 54.44 & 53.53 & 459 & 71 & 124 \\
\hline & SD & 6.56 & 4.31 & 6.57 & 6.64 & 3.55 & 3.75 & & & \\
\hline & Max & 109.76 & 107.23 & 134.40 & 77.99 & 59.58 & 60.05 & & & \\
\hline & Min & 92.70 & 92.67 & 115.49 & 57.62 & 49.37 & 46.31 & & & \\
\hline \multirow[t]{4}{*}{ As } & Mean & 25.11 & 19.10 & 19.34 & 11.32 & 7.57 & 5.81 & 33 & 1.5 & 7.24 \\
\hline & SD & 2.88 & 3.69 & 2.09 & 2.08 & 2.03 & 0.58 & & & \\
\hline & Max & 30.04 & 23.34 & 22.37 & 13.92 & 11.41 & 6.79 & & & \\
\hline & Min & 21.20 & 13.18 & 15.12 & 7.76 & 5.34 & 4.96 & & & \\
\hline
\end{tabular}

$\mathrm{Pb}$ is extremely toxic to most life forms, especially aquatic organisms. $\mathrm{Zn}$ is another essential nutrient for life; it activates enzymes. It is found in food and drinking water in the form of salts or organic complexes (Diop et al., 2015). The main sources of $\mathrm{Zn}$ contamination of the aquatic environment are zinc-containing fertilizers, effluents from treatment plants and mining. Urban runoff, mine drainage and municipal wastewater are the most concentrated sources of zinc in water. Arsenic is found in the earth's crust, in minerals in the form of amorphous and crystalline dust. In some areas the concentration of arsenic can be higher than normal and creates serious health hazards for humans and animals. It enters the environment through natural weathering of rocks, mining and smelting processes, pesticide use and coal combustion. The results showed arsenic contents that exceeded PEC, UCC reference and ISQG values.

\section{Contamination and accumulation of heavy metals and arsenic in sediments}

Table 2 shows the values of contamination factors (CF) and pollution load indices (PLI) for heavy metals and arsenic in sediment from the Tishgo and Chia rivers. In the Tishgo River, all the $\mathrm{CF}$ for $\mathrm{Cu}$ and $26 \%$ of the $\mathrm{CF}$ for $\mathrm{Pb}$ resulted less than one $(\mathrm{CF}<1)$ qualifying for both heavy metals as low CF. Seventy-four percent of the $\mathrm{CF}$ for $\mathrm{Pb}$ and $100 \%$ of the $\mathrm{CF}$ for $\mathrm{Zn}$ were between 1 and 3, qualifying as moderate CF. In the case of As, $100 \%$ of the CF were greater than six $(\mathrm{CF}>6)$, qualifying as high $\mathrm{CF}$. In the Chia River, $100 \%$ of the $\mathrm{CF}$ for $\mathrm{Cu}, 100 \%$ of the $\mathrm{CF}$ for $\mathrm{Pb}$ and $93 \%$ of the $\mathrm{CF}$ for $\mathrm{Zn}$ were less than one $(\mathrm{CF}<1)$ qualifying as low $\mathrm{CF}$. Seven percent of the $\mathrm{CF}$ for $\mathrm{Zn}$ were between 1 and 3 (moderate $\mathrm{CF}$ ), $63 \%$ of the $\mathrm{CF}$ for As were between 3 and 6 (considerable $\mathrm{CF}$ ) and $37 \%$ of the $\mathrm{CF}$ were greater than $6(\mathrm{CF}>6)$, qualifying as high $\mathrm{CF}$. Based on these results, a high As contamination condition is observed for both rivers. The results of the pollution load indexes (PLI) for heavy metals and As of the Tishgo and Chia rivers ranged from 1.657 to 2.337 and from 0.732 to 1.418 , respectively. The PLI results for the Tishgo River were greater than one (PLI > 1) denoting the environmental deterioration that this river has been experiencing. The highest PLI values were recorded at sampling sites $\mathrm{S} 3$ to $\mathrm{S} 9$, corresponding to the lower part of the river course. In the Chía River, $60 \%$ of the sampling sites indicated that there is no appreciable contamination by these elements (PLI $<1$ ). However, $40 \%$ of the sampling sites indicated PLI environmental deterioration (PLI > 1), middle and upper part of the Chia River course.

Figure 3 shows the geo-accumulation index $\left(\mathrm{I}_{\text {geo }}\right)$ values for heavy metals and arsenic recorded 

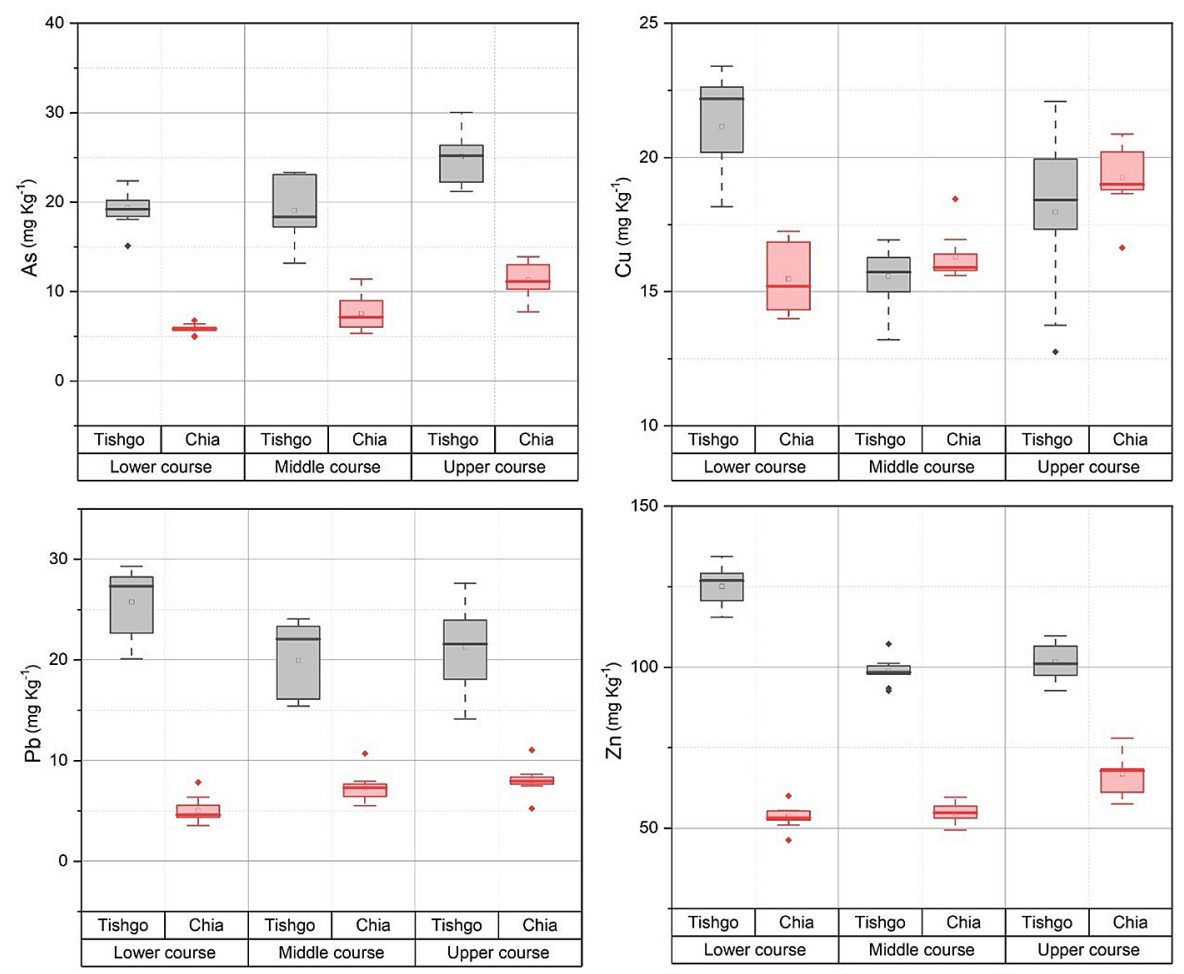

Figure 2. Distribution of heavy metals and arsenic in sediment of the Chia and Tishgo rivers in central Peru.

in sediment from the Tishgo and Chia rivers. In the Tishgo River, the $\mathrm{I}_{\text {geo }}$ values obtained for $\mathrm{Cu}$ and $\mathrm{Pb}$ indicated that the sampling sites are not contaminated by these metals $\left(\mathrm{I}_{\mathrm{geo}}=0\right)$ ). $52 \%$ of the $\mathrm{I}_{\text {geo }}$ showed an upward trend, $0>\mathrm{I}_{\text {geo }}<1$, denoting that the sampling sites are slightly contaminated. The As $I_{\text {geo }}$ values at all sampling sites ranged from 3 to 4 , indicating that the sediments at these sites are heavily contaminated. In the Chia River, the Igeo obtained for $\mathrm{Cu}, \mathrm{Pb}$ and $\mathrm{Zn}$ indicated that the sampling sites are not contaminated by these metals $\left(I_{\text {geo }}=0\right)$. However, the $I_{\text {geo }}$ values for As ranged from 1.14 to 2.63, indicating variability in the state of contamination, from moderately to severely contaminated.

\section{Assessment of potential ecological risk}

Table 3 shows the ecological risk values generated by each heavy metal and As evaluated. In the Tishgo River, the ecological risk values found for $\mathrm{Cu}, \mathrm{Pb}$ and $\mathrm{Zn}$ are $<40$, qualifying as low ecological risk. However, in $88 \%$ of the sampling sites the ecological risk values for As were found to be in the range of 80 to 160 , qualifying as considerable ecological risk. In the remaining $22 \%$ of the sampling sites the ecological risk values for As were $>160$, qualifying as high ecological risk.
The potential ecological risk index (Ri) is a complex pollution index resulting from the sum of the risk factors (Er) (Williams \& Antoine, 2020). Regarding the potential ecological risk index (Ri), it was found that $51 \%$ of the sampling sites presented a moderate $\mathrm{Ri}(150 \leq \mathrm{Ri}<300)$. While $49 \%$ of the sampling sites presented a low $\mathrm{Ri}(\mathrm{Ri}<$ $150)$. In the Chía River, the ecological risk values found for $\mathrm{Cu}, \mathrm{Pb}$ and $\mathrm{Zn}$ are $<40$, qualifying as low ecological risk. In 59\% of the sampling sites the ecological risk values for As were found in the range of 40 to 80 , qualifying as moderate ecological risk. In 11\% the ecological risk values for As qualified as considerable ecological risk and 30\% as low ecological risk. The Ri along the course of the Chia River qualified as low $(<150)$.

Figure 4 shows the behavior of the potential ecological risk index for both rivers. In the Tishgo River it can be observed that in several sampling sites the Ri values were $>150$, indicating a moderate potential ecological risk index. The sampling sites that exceeded the value of 150 corresponded to the middle and upper reaches of the Tishgo River. In the Chia River, none of the sampling sites exceeded the marked limit, indicating a low potential ecological risk index along the course of the Chia River. However, the results of this index indicate an ascending behavior in this river. 
Table 2. Contamination factor and pollution load index (PLI) of heavy metals and arsenic in sediments of Tishgo and Chia rivers.

\begin{tabular}{|c|c|c|c|c|c|c|c|c|c|c|}
\hline \multirow{3}{*}{ Sampling site } & \multicolumn{5}{|c|}{ Tishgo River } & \multicolumn{5}{|c|}{ Chía River } \\
\hline & \multicolumn{4}{|c|}{ Contamination Factor (CF) } & \multirow{2}{*}{ PLI } & \multicolumn{4}{|c|}{ Contamination Factor (CF) } & \multirow{2}{*}{ PLI } \\
\hline & $\mathrm{Cu}$ & $\mathrm{Pb}$ & $\mathrm{Zn}$ & As & & $\mathrm{Cu}$ & $\mathrm{Pb}$ & $\mathrm{Zn}$ & As & \\
\hline 1 & 0.808 & 1.134 & 1.630 & 12.773 & 2.090 & 0.598 & 0.231 & 0.846 & 4.261 & 0.840 \\
\hline 2 & 0.727 & 1.006 & 1.627 & 14.913 & 2.052 & 0.573 & 0.218 & 0.778 & 3.895 & 0.784 \\
\hline 3 & 0.737 & 1.466 & 1.699 & 14.187 & 2.259 & 0.573 & 0.178 & 0.744 & 3.798 & 0.732 \\
\hline 4 & 0.936 & 1.294 & 1.764 & 13.473 & 2.316 & 0.690 & 0.278 & 0.739 & 3.308 & 0.828 \\
\hline 5 & 0.906 & 1.367 & 1.790 & 13.473 & 2.337 & 0.616 & 0.232 & 0.779 & 3.365 & 0.782 \\
\hline 6 & 0.823 & 1.084 & 1.820 & 12.273 & 2.113 & 0.560 & 0.184 & 0.780 & 3.898 & 0.748 \\
\hline 7 & 0.905 & 1.402 & 1.787 & 12.053 & 2.286 & 0.674 & 0.393 & 0.718 & 3.776 & 0.920 \\
\hline 8 & 0.892 & 1.412 & 1.846 & 12.813 & 2.336 & 0.608 & 0.318 & 0.652 & 4.016 & 0.844 \\
\hline 9 & 0.887 & 1.430 & 1.893 & 10.080 & 2.218 & 0.682 & 0.228 & 0.749 & 4.525 & 0.852 \\
\hline 10 & 0.629 & 0.771 & 1.415 & 11.493 & 1.676 & 0.678 & 0.365 & 0.695 & 3.561 & 0.885 \\
\hline 11 & 0.528 & 0.773 & 1.406 & 13.640 & 1.673 & 0.636 & 0.287 & 0.775 & 4.527 & 0.895 \\
\hline 12 & 0.648 & 0.841 & 1.510 & 12.233 & 1.781 & 0.738 & 0.276 & 0.695 & 5.989 & 0.960 \\
\hline 13 & 0.677 & 1.104 & 1.316 & 10.320 & 1.785 & 0.631 & 0.370 & 0.756 & 3.662 & 0.896 \\
\hline 14 & 0.677 & 1.177 & 1.384 & 8.787 & 1.764 & 0.633 & 0.333 & 0.748 & 4.042 & 0.893 \\
\hline 15 & 0.651 & 0.806 & 1.426 & 11.587 & 1.716 & 0.656 & 0.322 & 0.771 & 4.763 & 0.939 \\
\hline 16 & 0.600 & 1.204 & 1.386 & 15.547 & 1.986 & 0.624 & 0.535 & 0.839 & 4.959 & 1.086 \\
\hline 17 & 0.613 & 1.127 & 1.305 & 15.560 & 1.935 & 0.632 & 0.398 & 0.821 & 6.329 & 1.069 \\
\hline 18 & 0.585 & 1.167 & 1.377 & 15.407 & 1.950 & 0.640 & 0.384 & 0.800 & 7.608 & 1.106 \\
\hline 19 & 0.510 & 0.904 & 1.373 & 17.580 & 1.827 & 0.808 & 0.262 & 0.812 & 6.116 & 1.013 \\
\hline 20 & 0.550 & 0.708 & 1.306 & 14.827 & 1.657 & 0.746 & 0.418 & 0.862 & 5.172 & 1.086 \\
\hline 21 & 0.734 & 0.759 & 1.396 & 18.627 & 1.951 & 0.775 & 0.374 & 0.926 & 7.425 & 1.188 \\
\hline 22 & 0.693 & 1.354 & 1.315 & 20.027 & 2.229 & 0.666 & 0.389 & 0.843 & 9.279 & 1.193 \\
\hline 23 & 0.737 & 1.079 & 1.542 & 17.180 & 2.142 & 0.752 & 0.398 & 0.956 & 7.984 & 1.229 \\
\hline 24 & 0.798 & 1.017 & 1.546 & 16.800 & 2.143 & 0.760 & 0.406 & 1.047 & 7.239 & 1.237 \\
\hline 25 & 0.756 & 1.174 & 1.495 & 16.727 & 2.171 & 0.830 & 0.553 & 0.964 & 9.149 & 1.418 \\
\hline 26 & 0.809 & 1.198 & 1.501 & 14.787 & 2.154 & 0.760 & 0.383 & 1.098 & 6.841 & 1.216 \\
\hline 27 & 0.883 & 1.381 & 1.424 & 14.133 & 2.226 & 0.835 & 0.432 & 0.961 & 8.683 & 1.317 \\
\hline
\end{tabular}

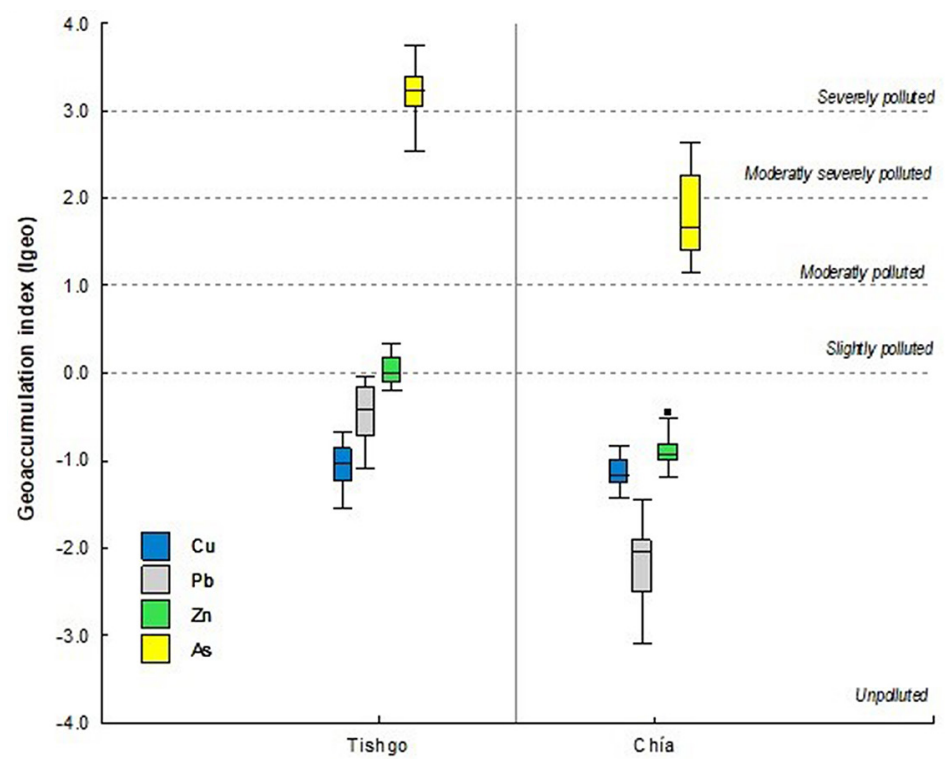

Figure 3. Geo-accumulation indices obtained from sediment samples of the Tishgo and Chia rivers. 
Table 3. Ecological risk factor (Er) and potential ecological risk index (Ri) of heavy metals and arsenic in sediment of the Tishgo and Chia rivers.

\begin{tabular}{|c|c|c|c|c|c|c|c|c|c|c|}
\hline \multirow{3}{*}{ Sampling site } & \multicolumn{5}{|c|}{ Tishgo } & \multicolumn{5}{|c|}{ Chía } \\
\hline & \multicolumn{4}{|c|}{ Ecological risk } & \multirow{2}{*}{$\mathrm{Ri}$} & \multicolumn{4}{|c|}{ Ecological risk } & \multirow{2}{*}{$\mathrm{Ri}$} \\
\hline & $\mathrm{Cu}$ & $\mathrm{Pb}$ & $\mathrm{Zn}$ & As & & $\mathrm{Cu}$ & $\mathrm{Pb}$ & $\mathrm{Zn}$ & As & \\
\hline 1 & 4.04 & 5.67 & 1.63 & 127.73 & 139.07 & 2.99 & 1.15 & 0.85 & 42.61 & 47.60 \\
\hline 2 & 3.63 & 5.03 & 1.63 & 149.13 & 159.42 & 2.86 & 1.09 & 0.78 & 38.95 & 43.68 \\
\hline 3 & 3.69 & 7.33 & 1.70 & 141.87 & 154.58 & 2.86 & 0.89 & 0.74 & 37.98 & 42.48 \\
\hline 4 & 4.68 & 6.47 & 1.76 & 134.73 & 147.65 & 3.45 & 1.39 & 0.74 & 33.08 & 38.66 \\
\hline 5 & 4.53 & 6.83 & 1.79 & 134.73 & 147.88 & 3.08 & 1.16 & 0.78 & 33.65 & 38.67 \\
\hline 6 & 4.11 & 5.42 & 1.82 & 122.73 & 134.09 & 2.80 & 0.92 & 0.78 & 38.98 & 43.48 \\
\hline 7 & 4.53 & 7.01 & 1.79 & 120.53 & 133.85 & 3.37 & 1.96 & 0.72 & 37.76 & 43.81 \\
\hline 8 & 4.46 & 7.06 & 1.85 & 128.13 & 141.49 & 3.04 & 1.59 & 0.65 & 40.16 & 45.44 \\
\hline 9 & 4.44 & 7.15 & 1.89 & 100.80 & 114.28 & 3.41 & 1.14 & 0.75 & 45.25 & 50.55 \\
\hline 10 & 3.15 & 3.86 & 1.41 & 114.93 & 123.35 & 3.39 & 1.83 & 0.70 & 35.61 & 41.52 \\
\hline 11 & 2.64 & 3.87 & 1.41 & 136.40 & 144.31 & 3.18 & 1.44 & 0.78 & 45.27 & 50.66 \\
\hline 12 & 3.24 & 4.20 & 1.51 & 122.33 & 131.28 & 3.69 & 1.38 & 0.70 & 59.89 & 65.66 \\
\hline 13 & 3.38 & 5.52 & 1.32 & 103.20 & 113.42 & 3.15 & 1.85 & 0.76 & 36.62 & 42.38 \\
\hline 14 & 3.39 & 5.88 & 1.38 & 87.87 & 98.52 & 3.16 & 1.67 & 0.75 & 40.42 & 46.00 \\
\hline 15 & 3.25 & 4.03 & 1.43 & 115.87 & 124.58 & 3.28 & 1.61 & 0.77 & 47.63 & 53.30 \\
\hline 16 & 3.00 & 6.02 & 1.39 & 155.47 & 165.87 & 3.12 & 2.68 & 0.84 & 49.59 & 56.23 \\
\hline 17 & 3.06 & 5.64 & 1.31 & 155.60 & 165.60 & 3.16 & 1.99 & 0.82 & 63.29 & 69.27 \\
\hline 18 & 2.92 & 5.83 & 1.38 & 154.07 & 164.20 & 3.20 & 1.92 & 0.80 & 76.08 & 82.00 \\
\hline 19 & 2.55 & 4.52 & 1.37 & 175.80 & 184.25 & 4.04 & 1.31 & 0.81 & 61.16 & 67.32 \\
\hline 20 & 2.75 & 3.54 & 1.31 & 148.27 & 155.86 & 3.73 & 2.09 & 0.86 & 51.72 & 58.40 \\
\hline 21 & 3.67 & 3.80 & 1.40 & 186.27 & 195.13 & 3.87 & 1.87 & 0.93 & 74.25 & 80.92 \\
\hline 22 & 3.46 & 6.77 & 1.31 & 200.27 & 211.81 & 3.33 & 1.94 & 0.84 & 92.79 & 98.91 \\
\hline 23 & 3.68 & 5.40 & 1.54 & 171.80 & 182.42 & 3.76 & 1.99 & 0.96 & 79.84 & 86.54 \\
\hline 24 & 3.99 & 5.09 & 1.55 & 168.00 & 178.62 & 3.80 & 2.03 & 1.05 & 72.39 & 79.27 \\
\hline 25 & 3.78 & 5.87 & 1.50 & 167.27 & 178.41 & 4.15 & 2.76 & 0.96 & 91.49 & 99.36 \\
\hline 26 & 4.05 & 5.99 & 1.50 & 147.87 & 159.40 & 3.80 & 1.91 & 1.10 & 68.41 & 75.23 \\
\hline 27 & 4.42 & 6.90 & 1.42 & 141.33 & 154.08 & 4.17 & 2.16 & 0.96 & 86.83 & 94.13 \\
\hline
\end{tabular}

\section{CONCLUSIONS}

The accumulation of metals in the sediments of rivers with fish farming potential can have a negative impact on aquatic ecosystems with repercussions on human health. Therefore, in this study, the sediment of the Tishgo and Chia rivers was analyzed to evaluate the contamination, accumulation and potential ecological risk of heavy metals and arsenic. The decreasing order of the mean concentrations of heavy metals and metalloid in the Chía River was $\mathrm{Zn}>\mathrm{Cu}>\mathrm{As}>\mathrm{Pb}$ and in the Tishgo River was $\mathrm{Zn}>\mathrm{Pb}>\mathrm{As}>\mathrm{Cu}$. In the Chia River, the highest mean concentrations of $\mathrm{Zn}, \mathrm{Cu}$, As and $\mathrm{Pb}$ were recorded in the upper course of the river. While in the Tishgo River, the highest mean concentrations were recorded in the lower course of the river. The mean concentrations of heavy metals and metalloids recorded in the rivers studied were lower than the threshold values of the probable effect concentration.
Based on the results, a high As contamination condition is observed for both rivers. The results of the pollution load indexes (PLI) of heavy metals and As for the Tishgo and Chia rivers ranged from 1.657 to 2.337 and from 0.732 to 1.418 , respectively. The PLI results for the Tishgo river were greater than one (PLI $>1$ ), indicating the environmental deterioration that this river has been experiencing. In the Chía River, $60 \%$ of the sampling sites indicated no appreciable contamination by these elements $(\mathrm{PLI}<1)$. The $\mathrm{I}_{\text {geo }}$ values of As in both rivers showed a state of contamination, from moderately to severely contaminated. In the Tishgo River the potential ecological risk ranged from low to moderate and in the Chia River from low to considerable.

The results of this research can be very useful for special measures to be adopted to control the entry of heavy metals with toxicological effects in the aquatic environments of the Tishgo and Chia rivers for the protection of these aquatic 


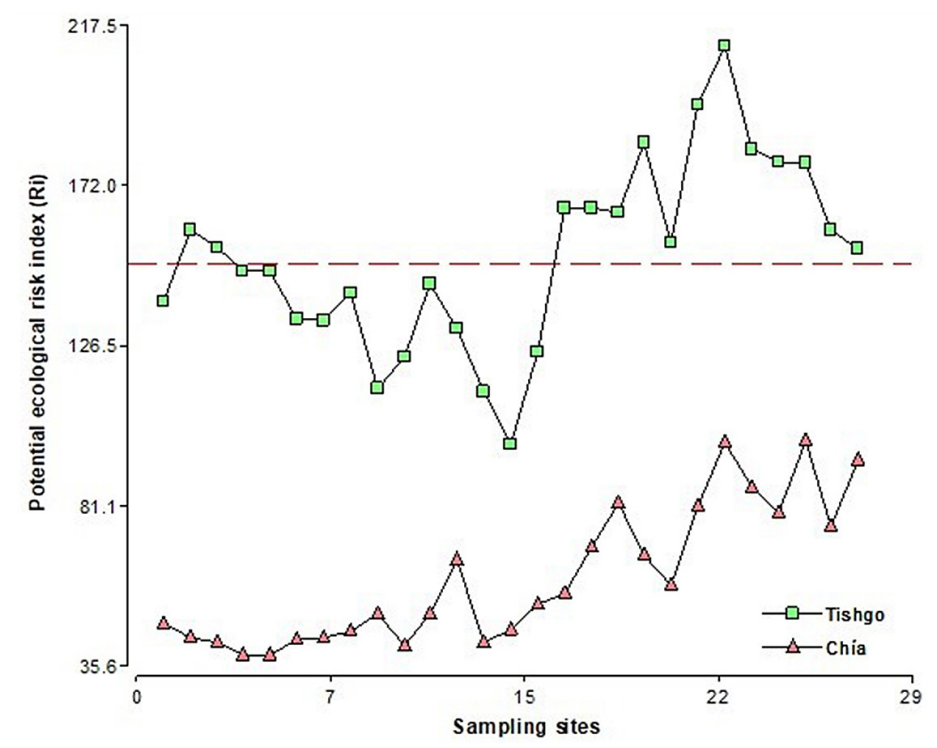

Figure 4. Potential ecological risk indexes recorded for sediments of the Tishgo and Chia rivers.

ecosystems and human health. The analysis of the data also reflects applicability and necessity of the evaluation indexes of contamination, accumulation and potential ecological risk of toxic metals.

\section{Acknowledgments}

The authors express our gratitude to the General Research Institute of the National University of Central Peru for the financing of the study.

\section{REFERENCES}

1. Arisekar, U., Jeya, R., Shalini, R., \& Jeyasekaran, G. (2020). Human health risk assessment of heavy metals in aquatic sediments and freshwater fish caught from Thamirabarani River, the Western Ghats of South Tamil Nadu. Marine Pollution Bulletin, 159(July), 111496. https://doi.org/10.1016/j. marpolbul.2020.111496

2. Barra-Rocha, C.H., Fernandes-Costa, H., \& Pimenta-Azevedo, L. (2019). Heavy metals in the São Mateus Stream Basin, Peixe River Basin, Paraiba do Sul River Basin, Brazil. Ambiente e Agua - An Interdisciplinary Journal of Applied Science, 14(3), 1-13. https://doi.org/10.4136/1980-993X

3. Cacchi Quiroz, E.A. (2019). Eficiencia de un filtro a base de Sphagnum magellanicum Brid. en el efluente del Centro Piscicola Ingenio, Huancayo. Universidad Nacional del Centro del Perú, Huancayo.

4. Canadian Council of Ministers of the Environment (CCME). (2004). Soil, Ground Water and Sediment Standards for Use Under Part XV. 1 of the Environmental Protection Act. Canadian Ministry of the Environmen.
5. Chanamé Zapata, F.C., Custodio Villanueva, M., Pantoja Esquivel, R.A., \& Unchupaico Payano, I.G. (2014). Bioaccumulation of heavy metals in Oncorhynchus mykiss for export at production centers in the Peruvian Central Highlands. Revista Ambiente e Agua, 9(3), 445-458. https://doi. org/10.4136/1980-993X

6. Custodio, M., Peñaloza, R., Chanamé, F., Yaranga, R., \& Pantoja, R. (2018). Assessment of the Aquatic Environment Quality of High Andean Lagoons using Multivariate Statistical Methods in Two Contrasting Climatic Periods. Journal of Ecological Engineering, 19(6), 24-33. https://doi. org/10.12911/22998993/92677

7. Dash, S., Borah, S.S., \& Kalamdhad, A.S. (2021). Heavy metal pollution and potential ecological risk assessment for surficial sediments of Deepor Beel, India. Ecological Indicators, 122(December 2020), 107265. https://doi.org/10.1016/j. ecolind.2020.107265

8. Davies, R.W., \& Govedich, F.R. (2001). Annelida: euhirudinea and acanthobdellidae. In Ecology and Classification of North American Freshwater Invertebrates (Second Edition). Academic Press, pp. 465-504.

9. Deng, P.Y., Shu, W.S., Lan, C.Y., \& Liu, W. (2008). Metal contamination in the sediment, pondweed, and snails of a stream receiving effluent from a lead/ zinc mine in southern China. Bulletin of Environmental Contamination and Toxicology, 81(1), 6974. https://doi.org/10.1007/s00128-008-9428-3

10. Diop, C., Dewaelé, D., Cazier, F., Diouf, A., \& Ouddane, B. (2015). Assessment of trace metals contamination level, bioavailability and toxicity in sediments from Dakar coast and Saint Louis estuary in Senegal, West Africa. Chemosphere, 138, 980-987. 
https://doi.org/10.1016/j.chemosphere.2014.12.041

11. El-Amier, Y.A., Elnaggar, A.A., \& El-Alfy, M. (2016). Evaluation and mapping spatial distribution of bottom sediment heavy metal contamination in Burullus Lake, Egypt. Egyptian Journal of Basic and Applied Sciences. https://doi.org/10.1016/j. ejbas.2016.09.005

12. Hakanson, L. (1980). An ecological risk index for aquatic pollution control.a sedimentological approach. Water Research, 14(8), 975-1001. https:// doi.org/10.1016/0043-1354(80)90143-8

13. Haris, H., Looi, L.J., Aris, A.Z., Mokhtar, N.F., Ayob, N.A.A., Yusoff, F.M., Salleh, A.B. Praveena, S.M. (2017). Geo-accumulation index and contamination factors of heavy metals $(\mathrm{Zn}$ and $\mathrm{Pb})$ in urban river sediment. Environmental Geochemistry and Health, 39(6), 1259-1271. https://doi.org/10.1007/ s10653-017-9971-0

14. Li, H., Lin, L., Ye, S., Li, H., \& Fan, J. (2017). Assessment of nutrient and heavy metal contamination in the seawater and sediment of Yalujiang Estuary. Marine Pollution Bulletin, 117(1-2), 499-506. https://doi.org/10.1016/j.marpolbul.2017.01.069

15. MacDonald, D.D., Ingersoll, C.G., \& Berger, T.A. (2000). Development and evaluation of consensusbased sediment quality guidelines for freshwater ecosystems. Archives of Environmental Contamination and Toxicology, 39(1), 20-31. https://doi. org/10.1007/s002440010075

16. Marshall, S.J. (2013). Hydrology. In Reference Module in Earth Systems and Environmental Sciences (pp. 1-4). Elsevier B.V. https://doi.org/10.1016/ B978-0-12-409548-9.05356-2

17. Meyer, J.L. (2010). Urban Aquatic Ecosystems. In Applied Aspectos of Inland Aquatic Ecosystem. Elsevier B.V., pp. 367-377.
18. Müller, G. (1979). Heavy Metals in the Sediment of the Rhine-Changes Seitt. Umschauin Wissenschaft Und Technik, 79, 778-783.

19. Ramírez, J., Roe, G., Sandoval Méndez, N., \& Vicente Cárdenas, K. (2018). Sistema Nacional De Innovación En Pesca Y Acuicultura - Fundamentos y propuesta 2017 - 2022. Lima-Perú.

20. Raza, A., Farooqi, A., Javed, A., \& Ali, W. (2016). Distribution, enrichment, and source identification of selected heavy metals in surface sediments of the Siran River, Mansehra, Pakistan. Environmental Monitoring and Assessment, 188(10). https://doi. org/10.1007/s10661-016-5586-7

21. Taylor, S.R., \& McLennan, S.M. (1995). The geochemical evolution of the continental crust. Reviews of Geophysics, 33(2), 241-265. https://oi. org/10.1029/95RG00262

22. Tomlinson, D.L., Wilson, J.G., Harris, C.R., \& Jeffrey, D.W. (1980). Problems in the assessment of heavy-metal levels in estuaries and the formation of a pollution index. Helgolander Meeresunters, 33, 566-575.

23. Varol, M. (2011). Assessment of heavy metal contamination in sediments of the Tigris River (Turkey) using pollution indices and multivariate statistical techniques. Journal of Hazardous Materials, 195, 355-364. https://doi.org/10.1016/j. jhazmat.2011.08.051

24. Williams, J.A., \& Antoine, J. (2020). Evaluation of the elemental pollution status of Jamaican surface sediments using enrichment factor, geoaccumulation index, ecological risk and potential ecological risk indexWilliams, Jhénelle A., and Antoine, Johann. 2020. Evaluation of the elemental pol. Marine Pollution Bulletin, 157(May), 111288. https://doi. org/10.1016/j.marpolbul.2020.111288 